\title{
RESEARCH and EVALUATION
}

\section{Comparing Local Fiscal Autonomy in the Water and Sanitation Sectors of Johannesburg and Nairobi}

Commonwealth Journal of Local Governance

Issue 13: November 2013

http://epress.lib.uts.edu.au/ojs/index.php/cjlg

\author{
Angelita Kithatu-Kiwekete \\ Graduate School of Public and Development Management \\ University of Witwatersrand, South Africa \\ Email:angelita.kithatu@gmail.com
}

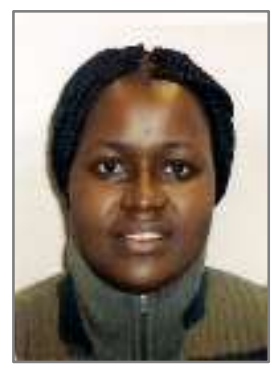

\begin{abstract}
The rationale for local fiscal autonomy suggests that local expenditure and local revenue generation should remain in close proximity. This is achieved through fiscal decentralisation to local government, to ensure efficient provision of local services that align with local needs, and to improve accountability to residents. Fiscal decentralisation has found resonance in developing countries through local government reforms, but in Africa fiscal decentralisation has been focussed mainly on revenue sharing, except in a few cases where some local fiscal autonomy has been achieved.

Urbanisation in Africa is likely to continue (UN-Habitat, 2008), necessitating an increase in municipal service delivery which African cities must finance - hence the need for local fiscal autonomy. Local fiscal autonomy is arguably contentious for African cities, partly because provision of municipal services must be tempered with considerations of equity and redistribution to the poorer urban populations, and because inadequate welfare nets from national government do not subsidise the gap in municipal revenue. In the recent past, Kenya and South Africa adopted local government reforms in different forms that has yielded different forms of local fiscal autonomy. The paper conducts a comparative of local fiscal autonomy in municipal services provision in Nairobi and Johannesburg.
\end{abstract}

Key words: revenue, African cities, Nairobi, Johannesburg, water services, user fees

\section{Introduction}

As African cities increase in size and economic output, urban governments face the unenviable challenge of providing a vast array of services to a diverse population. While one sector of the urban population has high technological and economic capacity, coupled with an ability to pay and a sophisticated demand for municipal services, poorer sectors of the city population require consistent access to basic urban services as a human right. It is to this diverse group that African cities should strive to provide municipal services. Questions then arise about the decisions that these cities make in maximising revenue for municipal expenditure - e.g. does the revenue assignment function cater for local preferences, and is local discretion evident in local revenue functions? 
This paper draws on a larger study that explores how two African cities with different revenue instruments leverage local revenue, to argue the need for local fiscal autonomy in African cities based on case studies of Nairobi and Johannesburg. The theoretical discussion on local fiscal autonomy is followed by an examination of user charges for water and sanitation services, as an example of a local revenue instrument, to argue for local political oversight and decentralised revenue management.

\section{Background}

Kenya and South Africa are the major economies in East and Southern African (IIAG, 2012). Kenya serves as an important avenue for exports and imports to neighbouring landlocked countries including Rwanda, Burundi and Uganda. Kenya is the largest economy in East Africa and the third largest in sub-Saharan Africa, and has the lion's shares of the East Africa's financial services and corporate headquarters (APRM, 2006: 17). South Africa dominates the sub-Saharan economic landscape and is (IIAG, 2012). Cities in both countries need local fiscal autonomy to meet the vast and diverse municipal expenditure needs that they face (UN-Habitat, 2009a: 10), and the diverse municipal populations of both Nairobi and Johannesburg continue to place a high demand on municipal services. It follows that the municipal mandate of both cities should correspond to the local revenue function.

Nairobi is over 100 years old with a colonial history. The city was chosen as a suitable stop between Mombasa and Kisumu during construction of the Kenyan Railway during the late 19th century. The city initially developed along racial lines with the former more affluent European areas better served by municipal services, while the African areas remained densely populated and under resourced (Obudho, 1997; Nangulu-Ayuku, 2000). In 2009 the city's population was estimated to be 3.7m, roughly $38 \%$ of Kenya's population (KNBS, 2010). The downside of rapid urbanization in cities such as Nairobi is the growing prevalence of slums and poverty in the under resourced regions of the city (UN-Habitat, 2009b: 119). Access to water and sewerage services remains problematic in these impoverished areas (Crow \& Odaba, 2010; Sammy, 2004).

Johannesburg came into existence a decade earlier than Nairobi in 1886. The city sprang up as a mining town and grew into a large city by the mid-20th century (Beavon, 1997). In 2011, the city's population was $4.4 \mathrm{~m}$ and is now South Africa's largest city with an economic base generating $16 \%$ of the country's gross domestic product (Stats SA, 2011; City of Johannesburg, 2006). Johannesburg also serves as the corporate headquarters for major banks and companies in Southern Africa (City of Johannesburg, 2006).

Historically, Johannesburg also developed along racial lines (Cameron, 2000; Bevon, 1997; Tomlinson, 1991). The city's residents in the impoverished former townships have limited access to water and sanitation, despite the city's valiant efforts to address redistribution of critical municipal services in line with national and international norms (CoJ, 2005: 30; Stats SA 2001, SACN, 2007 Richards, O’Leary \& Mutsonziwa, 2007). 
However, in both Kenya and South Africa, while the provision of water and sanitation is contentious, service provision remains the mandate of local government (K'Akumu, 2006; Nyangena, 2008; Crow et al, 2008; van Rooyen et al 2009). The rest of this paper explores how, within the discourse of fiscal decentralisation, local fiscal autonomy is manifests in the provision of services by the water utilities in Nairobi and Johannesburg. Finally the paper identifies emerging issues in relation to city oversight and local revenue management of basic services.

\section{Methodology}

This paper scrutinizes the experience of revenue autonomy with respect to water and sanitation services in Nairobi and Johannesburg. The findings are drawn from a larger study that examines the experience of local fiscal autonomy for specific revenue instruments in the two cities. The paper is based on an analysis of Kenyan and South African government documents including past and current legislation, policies, audited financial statements, and annual reports from the two water utilities.

Bahl and Martinez-Vazquez (2006) and Smoke (2001) identify the assignment of appropriate revenue tools to local government as important in the process of sequencing fiscal decentralisation. The provision of municipal services by local government heavily relies on the resources that local agencies have to finance municipal expenditure. They argue that, even with an intergovernmental fiscal transfer system, cities with administrative and managerial capacity should have the authority to generate revenue locally.

Local revenue and user fees in particular enable cities to provide those services where the costs of provision are connected to levels of consumption, such as water and sanitation services. Although equity principles should underlie the provision of these vital service, user fees that reflect the economic cost of these services provides an opportunity for cities to leverage significant revenue. Where cities have the potential to generate significant local revenue, there is an argument for revenue autonomy, which should be reflected in city management of the water revenue generation and in local political oversight of the service. The case study contrasts how Nairobi and Johannesburg tackle these challenges.

\section{Theoretical considerations for local fiscal autonomy}

Fiscal decentralisation is defined in this paper as the delegation of fiscal resources to local government (Oats, 1999; Bird, 2000). Fiscal decentralisation may take two forms: revenue sharing and revenue assignment (Bahl, 1999). In revenue sharing, central government allocates revenue directly to local government through conditional or unconditional intergovernmental transfers. In revenue assignment, which is the focus of this paper, local government is given the mandate to raise revenue locally. In examining revenue assignment, three aspects are relevant: efficiency; processes, and local fiscal autonomy, as a basis for analysis, each examined in more detail below. 


\section{Efficiency}

Fiscal decentralization has been popularized by economists (Bird, 1993; Musgrave \& Musgrave, 1973; Oates, 1972; Oates, 1999; Tiebout 1956) who propose efficiency as an essential prerequisite for fiscal decentralization. The argument is made that fiscal decentralization is effective if there is a clear distinction between spheres of government, whereby local government performs specific local function with revenue-raising tools to finance the expenditure. This implies a reduced reliance on national government to finance local expenditure and enhances local fiscal autonomy.

Revenue assignment allows local government to access local revenue and claim local fiscal autonomy. However it also raises the possibility of adverse effects on local population or on wider spheres. These negative consequences may be felt in three domains: areas within the jurisdiction of local government; for the national government; or for the country as a whole.

First, evidence reveals that revenue assignment may increase the potential for corruption as the close proximity between local officials, politicians and residents may increase opportunities corruption in revenue collection or service provision (Koldstad \& Fjeldstad, 2006; Fjeldstad \& Semboja 2000). This occurs when the local government system lacks adequate measures of accountability, as has been the case with the property tax in Tanzania (Koldstad et al, 2006).

Second, local governments often do not have the capacity to administer revenue assignment. Inadequate physical and human resources, mean that local government is inhibited from generating significant local revenue. The detrimental effect of incapability is documented in the experience of developing economies (Asibuo, 1998; GoK, 1996; Sing and Moodley, 2003). In both Zambia and Botswana, the fiscal relationship between the different levels of government remains blurred which negatively affects local government revenue-raising capacity (Sharma, 2003; Maipose, 2003). Even where countries have a framework that provides for fiscal decentralisation, this does not always translate into increase revenue for local government. Ghana, for example, provides for fiscal decentralisation in the Constitution, bit in practice this has not occurred. In Zambia and Zimbabwe, local authorities also experience erosion of the local revenue-raising powers (Asibuo, 1998; Ndoro, 2010; Rubvuta, 2010). In addition, the weak local tax base prevents local government from mobilizing local revenue (Tannenwald, 2002).

Third, from a national perspective, fiscal decentralisation may erode fiscal tools operated by national government for economic stabilization. For example, income tax is important central government tax, and delegating tax collection to local government, means that central government has less access to revenue to manage national fiscal policy and the overall economy. Local fiscal autonomy may thus constrain national government from using tax reforms to regulate the economy when need arises (Jourmard \& Kongsrud, 2003: 19-22; Prud'homme, 1995). The argument has also been made that 
local fiscal autonomy may lead to a distortion of resource allocation and increase inter-jurisdictional disparities (Prud'homme, 1995; Heyns, 1995; Oates; 1999). This proposition was also reflected earlier by Tiebout (1956) who argues that local residents are more likely to relocate to communities where they receive maximum benefit for local services, thus 'voting with their feet'. These are therefore the factors that may mitigate against fiscal decentralisation.

\section{Fiscal decentralisation}

The processes and structures of fiscal decentralisation should allow for local revenue mobilisation. Literature broadly suggests that fiscal decentralisation includes several components. First is an adequate enabling environment reflected in political which is important in implementation as central governments in many countries in Africa, remain unwilling to delegate revenue tools (Sharma, 2003). Secondly, a promulgated legal framework is required. This should assign appropriate functions and appropriate revenue to sub-national governments to reduce the incidence of unfunded mandates that leaves local agencies responsible for services with no corresponding revenue, as happened in South Africa where municipalities were responsible for some aspects of health care with no funding. Local authorities should also be able to obtain investment capital from central government, capital markets or municipal stock, a critical resource for financing municipal infrastructure. Finally, developing an appropriate intergovernmental transfer system for revenue-sharing by different levels of government is important (Bahl \& Martinez-Vazquez, 2006; Smoke 2000a; 200b; 2001).

\section{Local fiscal autonomy}

In contrast to fiscal decentralization, local fiscal autonomy is achieved through taxing and borrowing powers granted to local government (Bird, 2000; Bahl 1999). Local fiscal autonomy provides a close link between local revenue-raising powers and local expenditure assignments, resulting in a high degree of accountability that stems from the proximity of local expenditure and finance (Laubach, 2005). Furthermore, local fiscal autonomy is seen to make government more responsive to local needs (Denters and Lawrence, 2005). In addition the discretion to mobilise local revenue through revenue assignment allows for innovations in economic activity, enables local government to explore new revenue sources, and presents opportunities for efficiency (Jourmard et al, 2003; Oates, 1999). The benefits of local revenue autonomy are three-fold: first, sub-national tax autonomy addresses the problem of vertical imbalances in fiscal decentralization, giving local government an opportunity significantly to increase local revenue raised; second, the use of local revenue instruments allows for discretion in budgeting, and finally municipal borrowing and creditworthiness is strengthened by revenue autonomy enabling local governments to finance long-term capital expenditure (Bahl et al, 2006: 22). Thus, local revenue assignment enhances the ability of local government to finance mandated local expenditure. The section below explores how the local revenue function is manifest in the provision of water and sanitation services in Nairobi and Johannesburg. 


\section{Revenue assignment for water and sanitation}

The provision of water and sanitation services is contentious terrain, particularly access and affordability for the urban poor when government opts to charge for the provision for this vital service (Crow and Odaba, 2010; Bond and Dugard, 2007; Public Citizen, 2004). Furthermore, the governance of water services reflects discrepancies that undermine the intended efficiencies in water supply (Estache \& Kouassi, 2002). In addition, reports from the minimal citizen participation in governance processes highlight the contentious nature of water services (Nyangena, 2008). Corruption has also been touted as a consequence of poor water governance (Butterworth and de la Harpe, 2009).

Historically, where residents pay for water consumption, the local authority water services fall into two categories, user fees or trading services (Cowden, 1968). This implies an 'ability to pay' whereby the water tariffs take into account the fixed infrastructure costs and variable costs of water supplies. Where municipal services charge user fees, evidence suggests that local governments are able to profit from the service (Bahl and Linn, 1992: 271; Cowden, 1968:116). On this basis water services become a viable revenue source for cities.

This paper proposes a framework that explores how local fiscal autonomy and revenue assignment are manifest in local government services through the analysis of the water and sanitation sectors of Nairobi and Johannesburg. The intention is to explore the contextual innovations and constraints that arise in these two cities. Both cities set up water utilities, which illuminate the intricate fiscal and political relationships inherent in local fiscal autonomy.

Two questions are addressed in this paper. First, the literature suggests that a regulatory framework is basic for revenue assignment to local government. This requires political will at national level to promulgate legislation to allow revenue assignment. What are the laws in place to enable the cities to finance the provision of water and sanitation services, how do the cities chose to implement the proposed legal framework?

Second, the discretion in implementing the regulatory framework will be examined to explore how cities' political and administrative leadership is used to leverage significant local revenue. This question explores how cities have restructured and how they manage this municipal function to generate local revenue. The following section compares the Nairobi and Johannesburg water utilities.

\section{Nairobi City Water and Sewerage Company}

Nairobi has been able to leverage significant municipal revenue, and now relies on national government to provide less than a quarter of the city's revenue (CCN, 2010). Historically, water and sewerage services have been provided as a municipal function by the city ${ }^{40}$. The provision of this

\footnotetext{
${ }^{40}$ Legislation mandating water and sanitation services provision was based on Clauses $178 \& 180$ of the defunct Local Government Act (1963) which proved inadequate to support the city's need for water/ sewerage services.
} 
municipal service was plagued by poor service delivery. The water department was "heavily centralized" with a structure designed in a way that made it 'vulnerable to political manipulation leading to gross inefficiency' (Sammy 2004: 16). Furthermore the water fund set up to enhance the revenue streams for this function had been depleted by 2001 (NCC, 1998; RoK, 2002a).

Figure 1: Institutional Framework for Nairobi City Water and Sewerage Company

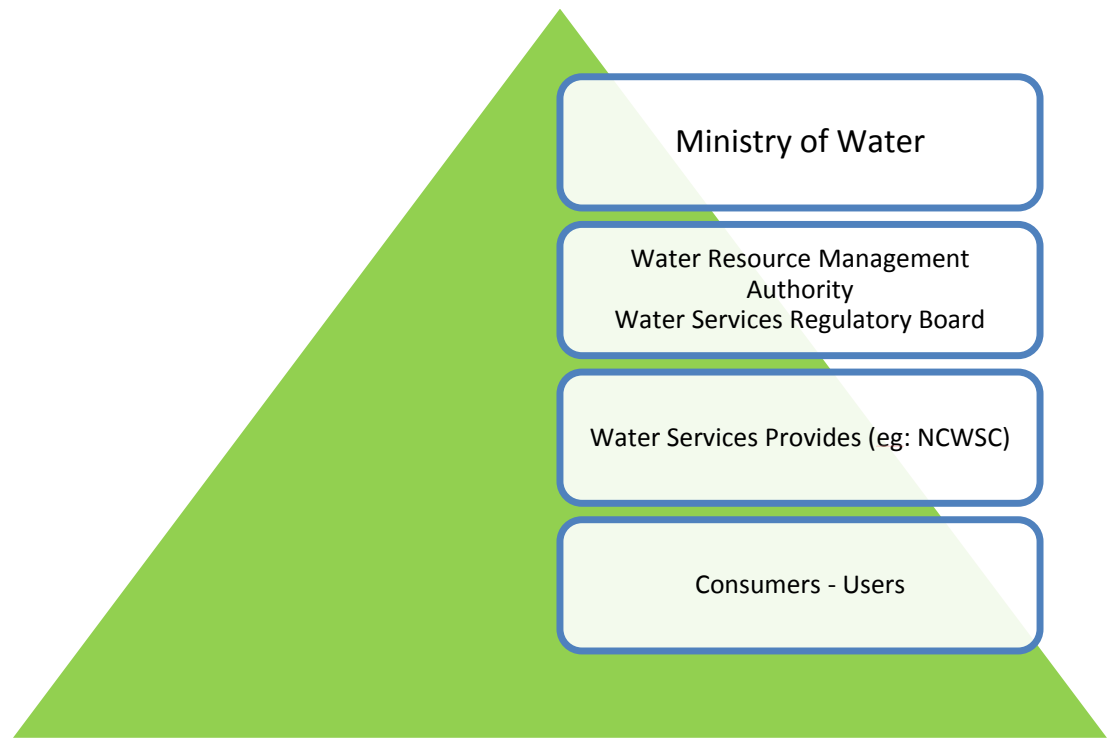

Source: Nairobi Water \& Sewerage Company website

A national effort to address issues of scarcity, access, and governance of water resources in Kenya saw the realignment of the institutional set-up in the provision of water services. Central government passed the Water Act (2002) ${ }^{41}$ whereby the Ministry of Water provides high-level guiding policy and oversight for water management (Figure 1) (RoK, 2002b). The regulations stipulate that water service providers be conveyers of water services and not local authorities as was previously the case.

Within this framework, the Nairobi City Water and Sewerage Company was established in 2003, to provide water and sanitation services to the city. The utility remains a subsidiary of Nairobi County ${ }^{42}$. Operational autonomy ensures that the entity is run as an enterprise to enhance efficiency and service provision. Autonomy also enables the water utility to function without 'political interference'. Management is overseen by an independent board drawn from private sector organizations, professional bodies, civil society and senior leadership of Nairobi County ${ }^{43}$. An important point to note is that, in line with the adoption of the new Kenyan Constitution in 2010 and the 2013 and general elections in Kenya, the utility continues to operate as a municipal function within the above framework (RoK, 2010; 2011).

\footnotetext{
${ }^{41}$ Although new legislation, the Kenya Constitution, the Urban Areas and Cities Act (2011) which came into effect on 4 March 2013, the regulatory framework for water services is derived from the Water Act (2002) (RoK, 2010; 2011)

${ }^{42}$ Under new legislation Nairobi City Council is replaced by Nairobi County after $4^{\text {th }}$ March 2013 (RoK, 2011).

${ }^{43}$ Previously Mayor; Town Clerk; and Town Treasurer sat on the water utility board, after March 2013 newly appointed Governor and County Secretary and Chief Officer now to represent Nairobi.
} 
A tri-partite agreement exists between Nairobi County, the water utility and Athi Water Service Board that manages the provision of water service delivery in Nairobi. The national legislation requires a service level agreement to be in place between the water utility and water provider, that is annually reviewed with predetermined targets and performance areas to measure service delivery (NCWSC, 2004: 5). Within this framework, water tariffs are annually determined for domestic and industrial consumers. The issues on political oversight in Nairobi for the city and revenue management will be examined further below, in comparison with experience with Johannesburg Water.

\section{Johannesburg Water}

Historically, the provision of water and sanitation services was the domain of white local authorities in the greater Johannesburg area including: Johannesburg; Randburg; Roodeport; Edenvale and the Sandton City Councils that raised local revenue from a vibrant economic base through various revenues streams (JCC, 1991; Simkins 1991). These authorities also traded services, including the wholesale domestic and industrial sale of water, electricity and gas ${ }^{44}$ to other local authorities. The revenue generated by other local authorities within the greater Johannesburg area was miniscule compared to white local authorities (AG, 1990; Simkins, 1991, Poto, 1989).

The fiscal disjuncture between Johannesburg's local authorities and others in the country was a contentious issue on the path to democracy in South Africa. The local government deliberations that took place alongside the national democratic process acknowledged the need to restructure the fiscal discrepancy between local authorities (CCLGA, 1991; CWMC, 1982; FWG, 1993; JCC, 1990a; 1990b; 1990c). Johannesburg's negotiation and transition phase was further protracted by the restructuring and eventual amalgamation of the diversely resourced local authorities of the greater Johannesburg area ${ }^{45}$ (PLANACT 1990, CWMC 1992). In 1993, the Local Government Transition Act (1993) merged Johannesburg's apartheid structures to form a two-tier metropolitan authority of the Greater Johannesburg Metropolitan Council and four metropolitan local councils: Northern, Southern, Eastern, Western Councils. These interim authorities were eventually merged into the City of Johannesburg under a Uni-City structure through the iGoli 2002 and iGoli 2010, the city development strategies adopted by the municipal council to provide coherence after the transition processes (GJMC, 2002). As metropolitan municipality, Johannesburg is mandated to provide municipal services including water and sanitation in parts B, Schedules 4 and 5 of the Constitution (RSA, 1996).

Johannesburg Water emerged from the restructuring process as the premier water and sanitation provider for Johannesburg. At inception, the water utility was managed at arm's length by a

\footnotetext{
${ }^{44}$ Trading services now referred to user fees although the intention of providing these services above cost is still retained (Cowden, 1968; Solomon, 1989)

${ }^{45}$ Local government's negotiation and transition to democracy took over a decade of political negotiations and municipal boundary demarcations during the pre-interim; interim and final phases of local government set out in the White Paper on Local Government (1998) (see CODESA, 1990; CCLGA1991; Cameron, 2000; 20053).
} 
consortium to 'streamline efficiency', revenue management, and integrate the disjointed physical and human infrastructure from previous local authorities (JW, 2003; 2004). The utility remains wholly owned by the City of Johannesburg operating with a vision to provide all municipal residents of Johannesburg with adequate water and sanitation services. The water utility remains a significant contributor to the city's revenue (CoJ, 2004; 2005; 2006; 2007; 2008; 2009).

Figure 2: Institutional Framework for Johannesburg Water

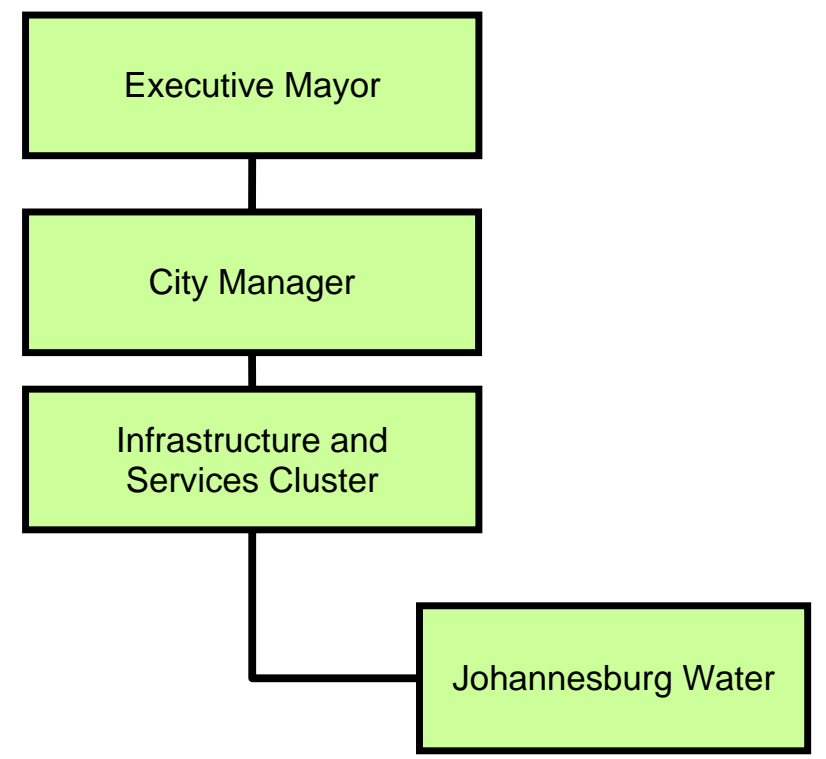

Source: City of Johannesburg, (2008: 13)

Figure 2 shows Johannesburg Water located under the Infrastructure and Services cluster in the city's administrative structure. Thus shows the city maintains oversight, although Johannesburg Water cooperates with Rand Water, at the water board responsible for bulk supply of water. Tariffs are set through the the City budget office as part of the city's annual budgeting processes in line with national treasury guidelines. The revenue function is managed by the city, although Johannesburg Water manages billing for the water utility's top customers (JW, 2001: 9; 2004: 4, 5; 2005: 20; 2010: 19).

\section{Emerging issues}

In both Nairobi and Johannesburg the water utilities have been instrumental in streamlining water and sanitation service delivery. Both operational efficiency, and the urban poor's access to water, have improved. However, from a fiscal perspective, several issues emerge as these cities assert local fiscal autonomy, explored below.

Johannesburg Water and Nairobi City Water and Sewerage Company are owned by their respective local governments. Closer scrutiny reveals that the level of independence of each utility differs particularly in the areas of revenue management and political oversight. As a significant contributor to city coffers, it is important that the customer billing function maximizes the revenue returns. The efficient management of this function enhances the payment levels which in turn enhances local 
revenue. Political oversight on the other hand is important for local fiscal autonomy to enhance accountability to local communities. Adherence to the regulatory framework in terms of local fiscal autonomy can then be confirmed, as discussed further below.

\section{Revenue management}

For Nairobi Water and Sewerage Company, water tariffs are set nationally by the Water Services Regulation Board (Figure 1). The utility manages the water revenue function, which includes billing of industrial and commercial consumers in the city; revenue collected from the sale of water to consumers is ring-fenced for the utility's expenditure (NCWSC, 2004: 5). While financial ringfencing is important for developing the utility and water infrastructure, Nairobi County Council's overall management has been curtailed, and the city has lost oversight over the water revenue stream. However, the tri-partite agreement in place between the city, water utility and water service board ensures that the Nairobi County Council receives a much smaller percentage of the water income than previously (Table 1$)^{46}$.

Table 1: Ten Year Revenue Trend from City Water Utilities

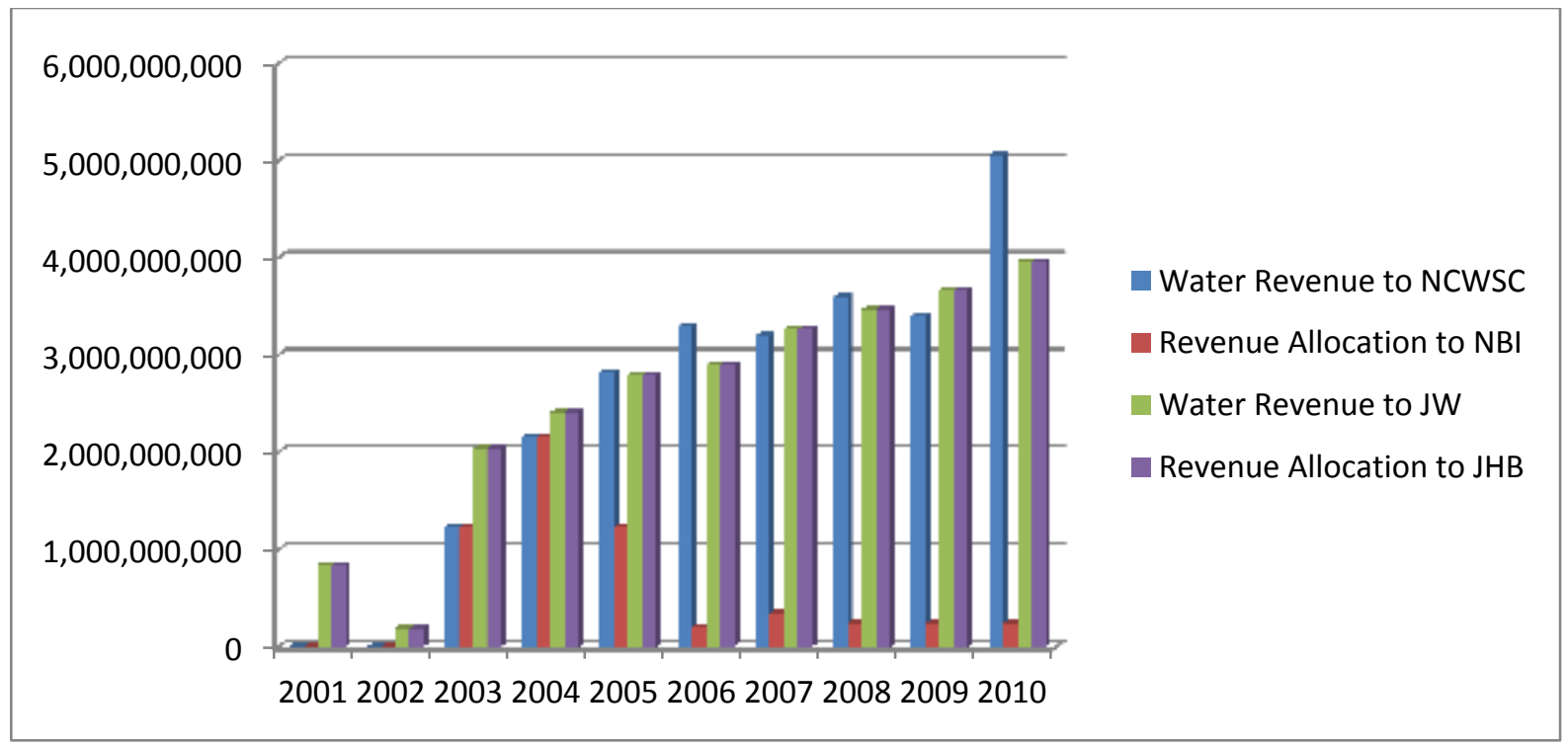

Source: Author ${ }^{47}$

Table 1 compares income to the water utilities in Nairobi and Johannesburg and the respective city councils between 2001 and 2010, the period when significant local government reforms were implemented. In the first two years NCWSC was not been established and services were operated by Nairobi's water and sewerage department, under severe fiscal constraints (MoLG, 2002). In the case of Johannesburg, utility revenue is appropriated so the income remains equal, as the city manages the revenue functions, which limits autonomy of Johannesburg Water (Smith, 2006: 11, 12).

\footnotetext{
${ }^{46}$ Nairobi also receives an additional transfer from central government to subsidise the revenue gap since the creation of utility in 2004 (NCC, 2008;2009)

${ }^{47}$ Pooled from Nairobi and Johannesburg audited financial statements from 2000 to 2010.
} 
Table 2 below reflects the revenue management function of the two cities, whereby control of each utility's revenue is compared between 2000 to 2010. Johannesburg Water initially controlled between 15\% and 40\% the water revenue function (JW, 2001: 9; 2004: 5; 2005:20), as Johannesburg Water managed the customer billing for the top customers from inception until 2010 (JW 2010: 12). Table 2 also illustrates that the City of Johannesburg has finally taken over full control over the water revenue function which includes customer management and billing. This centralised control further erodes the utility's revenue management.

Table 2: City management of Water Revenue function

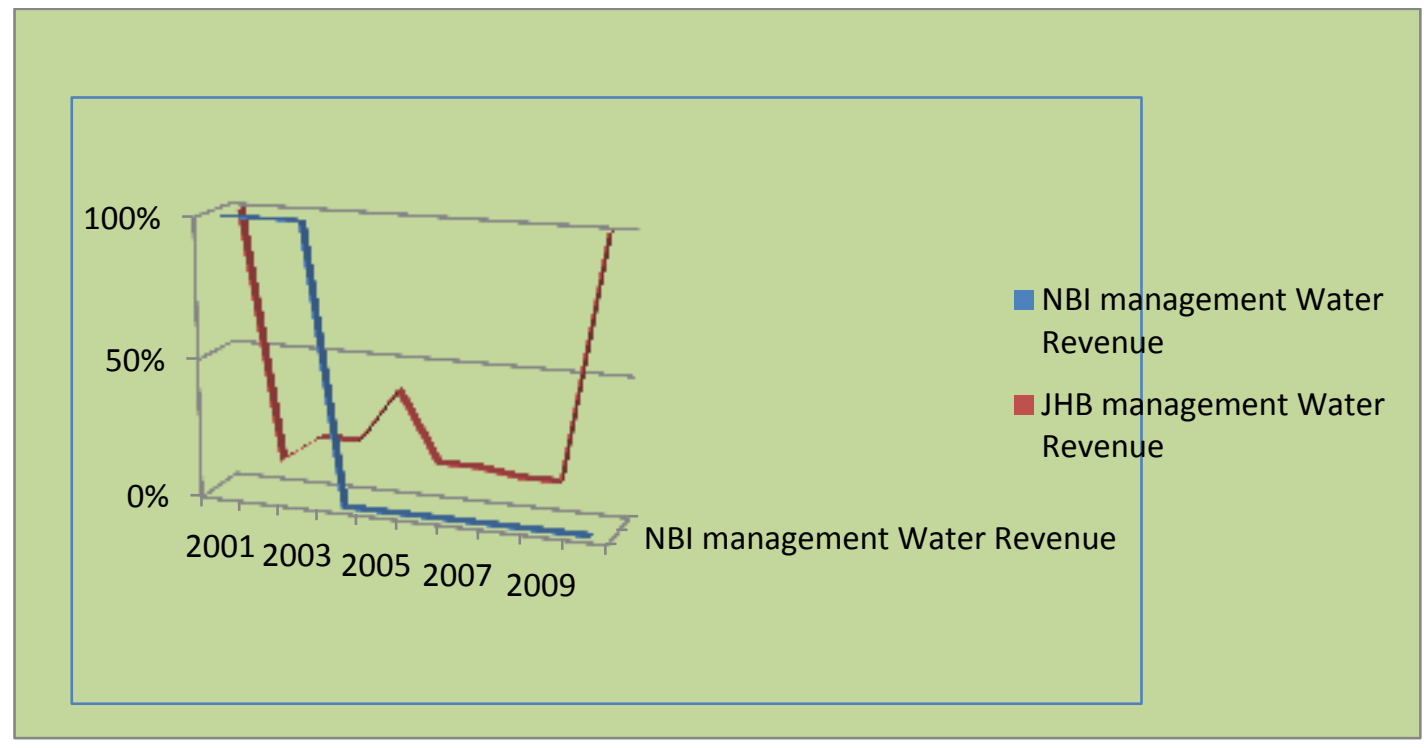

Source: author ${ }^{48}$

Conversely, Nairobi City Water and Sewerage Company as a water utility still independently manages the revenue function as legally prescribed with an annual disbursement to Nairobi County Council. The management of water revenues by the urban government has been severely eroded as a result. Therefore although the water revenue for both cities has increasing, local management of this revenue stream is reflected differently for these two cities.

\section{Political oversight:}

Political oversight is important in enhancing local fiscal autonomy, which assumes that overall control of local revenue remains as close as possible to local expenditure for the purposes of efficiency. In the case of Johannesburg Water, the City of Johannesburg continues to maintain political oversight through the political structures of the municipal councils; portfolio committees and engagement with Johannesburg Water's Board. The city's political accountability is also enhanced with increased revenue for redistribution. This has been evident in the provision of municipal services in previously disadvantaged areas as well as improved water infrastructure in various regions across the city that translates to access to a basic level of water services in line with human rights' standards (CoJ, 2005).

\footnotetext{
${ }^{48}$ These percentages were pulled from annual reports of both water utilities.
} 
The independent board of directors for Nairobi City Water and Sewerage Company are nominated from the private sector, professional bodies and non-governmental organisations. Political representation of Nairobi County Council constitutes five members on the utility's governance board, which has reduced the city's oversight function on the water utility. This distance from utility acts as a counterbalance to political interference as was the case in the past but, from a political accountability perspective, the city has less revenue for redistribution and has not seen an improvement of water infrastructure in impoverished areas of the city (K'Akumu, 2007: 533).

\section{Conclusion}

Local fiscal autonomy remains an important discourse in municipal service delivery for urban governments. City governments are tasked with providing a vast array of municipal services to a diverse and growing municipal population, but it is imperative that local governments have corresponding powers to over local revenue raising and expenditure to enhance efficiency and political accountability.

In the case of water and sanitation services, Johannesburg Water and Nairobi City Water and Sewerage Company are water utilities owned by the city governments of Johannesburg and Nairobi respectively; both cities have seen an upward trend in revenue collection. In the case of Johannesburg although the revenue function is managed centrally by the municipality, to the detriment of Johannesburg Water's customer billing function, the city's political accountability is enhanced as indicated earlier. Nairobi's experience differs in that its water utility independently manages the revenue function and the city's oversight is limited to city representation in the board of directors. This limited political oversight has reduced city interference with the utility's revenue, but also decreased the city's overall accountability in the provision to water services to the city.

The importance of these two aspects of local revenue functions for the cities' local fiscal autonomy continues to highlight concerns over the governance capacity of growing African cities, and how local governments can meet the increasing demand for municipal services in the current period of economic growth. Two questions are key. Do trading services such as water and sanitation remain the exclusive domain of local government, and what are the implications for local fiscal autonomy of the city of different levels of autonomy of water utilities? Secondly, in the increasing debate for revenue assignment and in African cities, does the institutional framework enable central government to erode water revenues of this local function?

\section{References}

Asibuo S.K. (1998) Funding Strategies for Local Government in Africa Africa Insight 28(3/4) 146-153.

Bahl R.W., and Linn, JF. (1992), Urban Public Finance in Developing Countries, New York: Oxford University Press.

Bahl R., (1999) Fiscal Decentralisation and Development Policy in Public Budgeting and Finance, 19(2) 59-75. 
Bahl, R., \& Martinez-Vazquez J., (2006), Sequencing Fiscal Decentralisation, World Bank Policy Research Working Paper 3914.

Beavon K. S. C. (1997) Johannesburg: A city and Metropolitan area in transformation in Rakodi C (ed), The Urban Challenge in Africa: Growth and Management of its large cities, Tokyo: United Nations University Press.

Bird R. M. (1993) Threading the Fiscal Labyrinth: Some Issues in Fiscal Decentralization. In National Tax Journal 46 (18) 207-228.

Bird R.M. (2000) Sub national Revenues: Realities and Prospects Washington: The World Bank.

Bond P., \& Dugard J., (2008) The case of Johannesburg water: What really happened at the pre-paid Parish pump Law, Democracy and Development, 12 (1) 1 -28.

Butterworth J., \& de la Harpe J., (2009) Not so petty: Corruption risks in payment and licensing systems for water CMI U4 Brief No.26, Bergen: Chr Michelsen Institute

Cameron R, (2000), Megacities in South Africa: A Solution for the New Millennium, Public Administration and Development, 25: 329 - 339.

Cowden J.W., (1968) Holmes' Local Government Finance ( $2^{\text {nd }}$ edition), Durban: Butterworths.

Crow B., \& Odaba, E., (2010) Access to Water in a Nairobi Slum: Women's work and institutional learning: in Water International, 135 (6) 733 - 747.

Denters, B. \& Lawrence, E.R. (2005), Comparing Local Governance: Trends and Developments. New York: Palgrave Macmillan.

Estache A, Kouassi E., (2002), Sector Organization, Governance and The Inefficiencies of African Water Utilities, World Bank Policy Research Working Paper 2890.

Fjeldstad O-H, \& Semboja J (2000) Dilemmas of Fiscal Decentralisation: A Study of Local Government Taxation in Tanzania in Forum for Development Studies 27(1) 7-41.

Heyns J.v.D.S. (1995), Equity and Redistribution in South Africa: Some Fiscal Federalism Perspectives in The South African Journal of Economics 63(2) 153-172.

(IIAG) (2012) Ibrahim Index of African Governance, Swindon: Mo Ibrahim Foundation available at http://www.moibrahimfoundation.org/downloads/2012-IIAG-summary-report.pdf

Jourmard I., \& Kongsrud P.M. (2003) Fiscal relations across government levels, OECD Working Paper ECO/WKP 29.

K'Akumu O.A. (2007), Towards effective governance of water services in Kenya in Water Policy 1 9: 529 -543.

Koldstad J, \& Fjeldstad O.H. (2006), Fiscal Decentralization and Corruption: A Brief Overview of the Issues U4 Chr Michelsen Institute, Issue 4.

Laubach, T. (2005), Fiscal Relations across Levels of Government in the United States, OECD Working Paper, ECO/WKP (2005) 49.

Maipose, G. (2003). Local Government Financing in Zambia: Challenges of Decremental Budgeting, Local Capacity Building and Unfunded Mandate in Reddy, P.S. Sing, D. Moodley, S (eds) Local Government Financing and Development in Southern Africa. Cape Town: Oxford University Press.

Musgrave R.A., \& Musgrave P.B. (1973) Public Finance in Theory and Practice New York: Mcgraw Hill.

Nangulu-Ayuku A, (2000), Politics Urban Planning and Population Settlement: NBI 1912-1916 Journal of Third World Studies Americas Fall 17 (2): 171-205.

Ndoro C., (2010), Zimbabwe in (EISA) Electoral Institute of Southern Africa (2010) Resourcing the Local State: Local Government and Revenue Raising, Johannesburg: EISA.

Nyangena K.O., (2008), Privatisation of Water and Sanitation Services in Kenya: Challenges and Prospects in Africa Development, XXXIII (4)117-131.

Oates W, (1972) Fiscal Federalism Harcourt: Brace Jovanovich Inc.

Oates W.E. (1999) An Essay on Fiscal Federalism, in Journal of Economic Literature, 37(3) 1120-1149.

Obudho R. A. (1997), Nairobi National Capital and Regional Hub, in Rakodi C (ed), The Urban Challenge in Africa: Growth and Management of its Large Cities, Tokyo: Unites Nations University Press.

PLANACT (1990), Local Government Finance; Electricity and the Impact of the Transvaal Rent Boycott, Paper prepared by Swilling M, Corbett W, \& Hunter R. 
Poto J., (1989) The Viability of Black Local Authorities in Heymans C, and Tötemeyer G (eds), Government By the People? Kenwyn: Juta \& Co Ltd.

Prud'homme R., (1995) Dangers of Decentralization in The World Bank Research Observer 10(2) 201-220.

Public Citizen, (2004), Orange Farm, South Africa: The Forced Implementation of Prepaid Meters, Washington: Public Citizen, available at www.wateractivist.org

Richards R., O’Leary B., \& Mutsonziwa K., (2007), Measuring the Quality of Life in Informal Settlements in South Africa in Social Indicators Research, 81(2) 375 - 388.

Rubvuta E., (2010), Zambia in Zimbabwe in (EISA) Electoral Institute of Southern Africa (2010) Resourcing the Local State: Local Government and Revenue Raising, Johannesburg: EISA.

(SACN), South African Cities Network (2007), State of Cities Finances Report 2007, Johannesburg: South African Cities Network.

Sammy W., (2004), Water Privatization in Kenya, Global Issue Papers No. 8, March 2004 Berlin: Heinrich Böll Foundation.

Sharma, K. (2003). Local Government Finance and Management: A Critical Factor in Development of Local Government in Botswana in Reddy, P.S. Sing, D. \& Moodley, S (eds) Local Government Financing and Development in Southern Africa. Cape Town: Oxford University Press.

Simkins C (1991) Local Government in South African Cities: Some Preliminary Notes in Politikon, 18(1) 4658.

Moodley S., and Sing D., (2003) Local Government Financing in South Africa in Reddy P.S., Sing D., \& Moodley S, (eds) Local Government Financing and Development in Southern Africa, Cape Town: Oxford University Press.

Smith L., (2006) Neither Public Nor Private: Unpacking the Johannesburg Water Corporatization Model, Geneva: United Nations Research Institute for Social Development, UNRISD.

Smoke P., (2000a), "Fiscal Decentralization in East and Southern Africa: A Selective Renew of Experience and Moving Forward" paper present at IMF Fiscal Decentralization Conference, November 20-21 Washington.

Smoke P., (2000b), Building Capacity for Effective Local Government in Developing Countries: Adapting the Garden Cities Concept, World Bank

Smoke P. (2001) Fiscal Decentralization in Developing Countries: A Review of Current Concepts and Practice, Geneva: UNRISD (United Nations Research Institute for Social Development).

Solomon D., (1989) The Financial and Fiscal Aspects of Local Government Restructuring in Heymans C, and Tötemeyer G (eds), Government By the People? Kenwyn: Juta \& Co Ltd.

Tomlinson R. (1991) Ten Years in The Making: The Evolution of Metropolitan Government in Johannesburg in Urban Forum 10 (1) 2-3.

Tiebout, C. (1956) A Pure Theory of Local Expenditures, Journal of Political Economy 64 (5)416-424

Tannenwald R., (2002) Are State and Local revenues Becoming Obsolete? in National Tax Journal, LV (3) 467-489.

(UN HABITAT) United Nations Habitat (2008), The State of the African Cities 2008: A Framework for addressing Urban Challenges in Africa Nairobi: UN-Habitat.

(UN HABITAT) United Nations Habitat (2009a), Guide To Municipal Finance, Nairobi: UN-Habitat.

(UN HABITAT) United Nations Habitat (2009b), State of the World's Cities 2008/2009: Harmonious Cities London, Sterling; VA: Earthscan.

(UN) United Nations (2008) The Millennium Development Goals Report, New York: United Nations

Van Rooyen C., De Wet T., Marais I., \& Korth, M., (2009) Johannesburg Case Study, The Water Dialogues. 


\section{Government Policies and Documents}

(APRM), African Peer Review Mechanism, (2006), Country Review Report of the Republic of Kenya, APRM.

(CSS) Central Statistics Service, (1991), Financial Statistics of Local Authorities and Regional Services Councils, quarter ended 30 June 1991.

CSS (1990), Financial Statistics of Local Government, New Release 1989/90, 2 December 1990.

(CCLGA) Council for the Co-ordination of Local Government Affairs, (1991), Report on the Recommendation of the Investigating Committee in A System of Local Government for South Africa on Key Aspects of Metropolitan Government, October 1991, chaired by Dr C Thornhill.

CWMC (1992) Resolution of Greater SOWETO Crisis: Finance and Services, working Document $9^{\text {th }}$ draft, 24 November 1992.

(CCN) City Council of Nairobi (2010), City Council of Nairobi Budget 2010/ 2011, Nairobi: City Council of Nairobi.

City of Johannesburg (2005) Human Development Strategy: Joburg's Commitment to the Poor Johannesburg: City of Johannesburg.

City of Johannesburg, (2006) Integrated Development Plan 2006/11, Johannesburg: City of Johannesburg.

City of Johannesburg, (2008) Overview of Johannesburg, Johannesburg: City of Johannesburg. Available at: www.joburg.org.za/key documents .

Davis A.H (1992) Managing in the Nu SA Structural Analysis: Problems and Solutions in Urban Infrastructure Management, City Engineers department SOWETO CC, Paper presented at the International Water Supply Association Seminar on Water and Sanitation for Developing Communities held 25 June 1992 ESKOM College Midrand, South Africa.

(FWG) Finance Working Group of the CWMC (1993) Financing CAPEX in a Metropolitan Context with Specific Reference to the World Bank, minutes of the $17^{\text {th }}$ meeting of the FWG 4 June 1993, Johannesburg Civic Centre, Johannesburg.

(GJMC) Greater Johannesburg Metropolitan Council (2002) iGoli 2002: Making Greater Joburg Work: Johannesburg: GJMC.

(RoK) Republic of Kenya, (1996), Report of the Commission of Inquiry on Local Authorities in Kenya: A Strategy for Local Government Reform in Kenya Nairobi: Government Printer.

(RoK) Republic of Kenya, (2002a), Ministry of Local Government/ Interim Oversight Board for Nairobi City Council. Nairobi City Council Financial Report.

(RoK) Republic of Kenya, (2002b), Water Act, No. 8 of 2002.

(RoK) Republic of Kenya, (2007a) Kenya Vision 2030: A Globally Competitive and Prosperous Kenya.

(RoK) Republic of Kenya, (2007b) Study on the Impact of the Local Authority Service Delivery Action Plan, Kenya Local Government Reform Programme, Ministry of Local Government September 2007. Available at www.localgovernment.go.ke/downloads

(RoK) Republic of Kenya, (2007c) Local Authorities Finance Diagnostics Study Kenya Local Government Reform Programme.

(RoK) Republic of Kenya, (2010), The Constitution of Kenya.

(RoK) Republic of Kenya, (2011), Urban Areas and Cities Act, No. 13 of 2011.

(JCC) Johannesburg City Council, (1990a), Transfer Payments Between Local Authorities: A Practical and Attainable Solution?, Paper developed by P Mathee, Deputy Town Clerk: Finance, Johannesburg City Council, 4 October 1990.

(JCC) Johannesburg City Council (1990b), Additional and Alternative Sources of Revenue for Local Authoritie $\underline{\text {, }}$ Memorandum Prepared by the City Treasurer's Departments of JCC on behalf of Municipal Treasurers and Accountants, July 1990.

(JCC) Johannesburg City Council (1990c), A Brief Memorandum Regarding Some of the Possible Methods of Financing A New Dispensation for Local Government,_ Prepared by the Research Branch of the City Treasurer's Department of JCC, July 1990. 
Johannesburg Water (2003) Business Plan 2003 to 2008.

Johannesburg Water (2005) Annual Report For Year Ended June 2004.

Johannesburg Water (2006) Annual Report For Year Ended June 2005.

Johannesburg Water (2007) Annual Report For Year Ended June 2006.

Johannesburg Water (2008) Annual Report For Year Ended June 2007.

Johannesburg Water (2009) Annual Report For Year Ended June 2008.

Johannesburg Water (2010) Annual Report For Year Ended June 2009.

(KNBS) Kenya National Bureau of Statistics (2010), 2009 Kenya Population and Housing Census, Nairobi: KNBS.

(NCWSC) Nairobi City Water and Sewerage Company (2004) Transition Business Plan, Nairobi: Nairobi City Water and Sewerage Company

(NCWSC) Nairobi City Water and Sewerage Company (2005) Annual Report and Financial Statements, Nairobi: Nairobi City Water and Sewerage Company.

(NCWSC) Nairobi City Water and Sewerage Company (2006) Annual Report and Financial Statements, Nairobi: Nairobi City Water and Sewerage Company.

(NCWSC) Nairobi City Water and Sewerage Company (2007) Annual Report and Financial Statements, Nairobi: Nairobi City Water and Sewerage Company.

(NCWSC) Nairobi City Water and Sewerage Company (2008) Annual Report and Financial Statements, Nairobi: Nairobi City Water and Sewerage Company.

(NCWSC) Nairobi City Water and Sewerage Company (2009) Annual Report and Financial Statements, Nairobi: Nairobi City Water and Sewerage Company.

(NCWSC) Nairobi City Water and Sewerage Company (2010) Annual Report and Financial Statements, Nairobi: Nairobi City Water and Sewerage Company.

NCWSC/AWSB (2009) Strategic Guidelines for Improving Water and Sanitation Services in Nairobi's Informal Settlements, Nairobi City Water and Sewerage Company (NCWSC) and Athi Water Services Board (AWSB) with the support of the Water and Sanitation Program - Africa (WSP-AF).

(RSA) Republic of South Africa, (1993), Local Government Transition Act, No. 209 of 1993.

(RSA) Republic of South Africa, (1996), The Constitution of the Republic of South Africa, No. 108 of 1996

(Stats SA) Statistics South Africa (2011), Census 2011: Municipal Fact Sheet available at http://www.statssa.gov.za/Census2011/Products/Census_2011_Municipal_fact_sheet.pdf accessed 8 April 2013. 